\title{
DETERMINATION OF HYDRAULIC CONDUCTIVITY BY THE AUGER- HOLE METHOD
}

\author{
DETERMINAÇÃO DA CONDUTIVIDADE HIDRÁULICA PELO MÉTODO DE AUGER-HOLE \\ Oswaldo Palma Lopes Sobrinho', Stephanie Soares Arriero ${ }^{2}$, Gerlange Soares da Silva ${ }^{3}$, Aline \\ Bezerra de Sousa ${ }^{4}$, Álvaro Itaúna Schalcher Pereira ${ }^{5}$ \\ ${ }^{1}$ Instituto Federal de Educação, Ciência e Tecnologia Goiano, Rio Verde, Goiás, Brasil - \\ oswaldo-palma@hotmail.com \\ 2, 3, 4 Universidade Federal do Recôncavo da Bahia, Cruz das Almas, Bahia, Brasil - \\ stephaniearriero@hotmail.com,gerlangesoares@hotmail.com \& alinelaugh@hotmail.com \\ ${ }^{5}$ Instituto Federal de Educação, Ciência e Tecnologia do Maranhão, Codó, Maranhão, Brasil - \\ alvaro.pereira@ifma.edu.br
}

\begin{abstract}
The hydraulic conductivity of a soil is the main parameter that determines its drainage capacity. However, its determination is of great importance for sizing in agricultural drainage systems. To determine the hydraulic conductivity of the soil in the presence of water table through the Auger-Hole. The experiment was carried out at Embrapa Manioc and Fruticulture (EMBRAPA), located in the municipality of Cruz das Almas-BA. In order to estimate the hydraulic conductivity, several empirical formulas have been proposed, such as Ernst's, which is the model that most closely approximates the soil situation studied. The hydraulic conductivity values for the studied soil obtained by the Auger-Hole method ranged from 0.24821 to $0.28544 \mathrm{~m}^{-1}$ day $^{-1}$. With an average value for hydraulic conductivity of $0.266835 \mathrm{~m} \mathrm{day}^{-1}$, being considered slow. The soil under analysis is classified in slow saturated hydraulic conductivity. The Auger-Hole method proved to be practical, fast, safe and easy to handle.
\end{abstract}

KEYWORDS: Agricultural drainage, Boring hole, Water table.

\section{RESUMO}

A condutividade hidráulica de um solo é o principal parâmetro que determina sua capacidade de drenagem. No entanto, sua determinação é de grande importância para dimensionamento em sistemas de drenagem agrícola. Determinar a condutividade hidráulica do solo na presença de lençol freático por meio do furo de trado Auger-Hole. O experimento foi realizado na Embrapa Mandioca e Fruticultura (EMBRAPA), localizada no município de Cruz das Almas-BA. Para estimar a condutividade hidráulica, foram propostas várias fórmulas empíricas, como a de Ernst, que é o modelo que mais se aproxima da situação do solo estudada. Os valores de condutividade hidráulica para o solo estudado obtidos pelo método Auger-Hole variaram de 0,24821 a 0,28544 $\mathrm{m} \mathrm{dia}^{-1}$. Com um valor médio para condutividade hidráulica de $0,266835 \mathrm{~m} \mathrm{dia}^{1}{ }^{1}$, sendo considerado lento. $\mathrm{O}$ solo em análise é classificado em condutividade hidráulica saturada lenta. O método Auger-Hole provou ser prático, rápido, seguro e fácil de manusear.

PALAVRAS-CHAVE: Drenagem agrícola, Furo de trado, Lençol freático. 


\section{INTRODUCTION}

For Gonçalves and Libardi (2013), the hydraulic conductivity of the soil is a property that expresses the ease with which the water moves in it, being of extreme importance to the agricultural use and, consequently, the production of the crops and the preservation of the soil and the environment.

According to Gaspar (2006), the evaluation is performed through the permeability coefficient, which can be determined directly through field and laboratory tests. This property is controlled by the porosity, structure and granulometry of soils.

Ferreira (2002), qualitatively, the hydraulic conductivity is of great importance in the characterization of porous media in permeable or conductive (low resistance to water passage), semipermeable (medium resistance) and low permeability (high hydraulic resistance) when their values result high, medium and low.

Guerra (2000) states that hydraulic conductivity is linked to a proportionality coefficient of the Darcy equation, which is used to determine the movement of fluids in porous media. In the soil, it expresses the ease with which the water moves in the profile.

The hydraulic conductivity of the saturated soil indicates the ability of a soil to transmit water in the unsaturated soil, this conductivity varies with the amount of water present in its empty pores, that is, with its degree of saturation. For this, the hydraulic conductivity has its maximum value in the saturated soil, being highly dependent on the volumetric humidity, and its value decreases markedly with the decrease of the humidity (SCHOSSLER et al., 2012).

There are several methods for determining hydraulic conductivity. These can be divided into laboratory and field methods. The most common laboratory methods are: constant charge permeability and variable charge. In the field, we highlight the methods that use the principle of continuous flow, such as the hole boring (well) and the constant flow.

The Auger-Hole drilling method is a simple, fast and accurate method, which is responsible for estimating the hydraulic conductivity of the saturated soil, the soil level between the water table and the bottom of the well. This method according to Feitoza (2006) is also known in the international literature as Auger-Hole method, has been widely used in drainage surveys because of its rapidity and representativeness of a considerable volume of natural soil, which tends to reduce the variability of the data.

In the soil, it expresses the ease with which the water moves in the profile. The aim of this work was to determine the hydraulic conductivity of the soil in the presence of water table through the Auger-Hole.

\section{MATERIAL AND METHODS}

The experiment was carried out at Embrapa Manioc and Fruticulture (EMBRAPA), located in the municipality of Cruz das Almas-BA, with geographic coordinates of $12^{\circ} 4^{\prime} \mathrm{S} ; 39^{\circ} 06^{\prime} \mathrm{W}$ and altitude of $225 \mathrm{~m}$. In the spring area, 3 readings (Figure 1 ) were taken from the soil with a diameter of 8 centimeters, using a tread, until the water table level was exceeded (Figure 2).

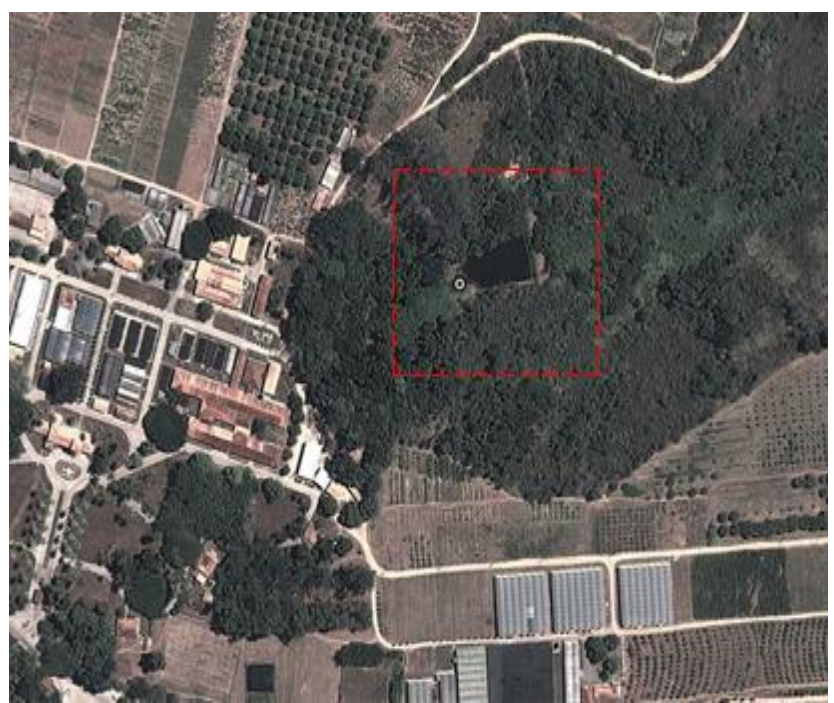

Figure 1. Location where the experiment was performed. Source: Google Earth (2017).

According to the classification of Köppen, the climate is of the type Af, that is to say, warm climate, with the coldest month with temperature above $18^{\circ} \mathrm{C}$ and the driest with precipitations equal or superior to $60 \mathrm{~mm}$. The average annual rainfall is $1,200 \mathrm{~mm}$, with the months of March to July being the rainiest and October and January the driest, with an annual average temperature of $24.2^{\circ} \mathrm{C}$ and relative humidity of $80 \%$ (D'ANGIOLELLA et al., 1998).

The soil of the experimental area is classified as Distrocoeso Yellow Latosol (SOUZA and SOUZA, 2001). After the well was opened, all excess water was removed in order to obtain the level of the sheet as zero, thus initiating the readings, since several hole tests were performed (Figure 2 A, B, C, D) until satisfactory conditions of readings. 

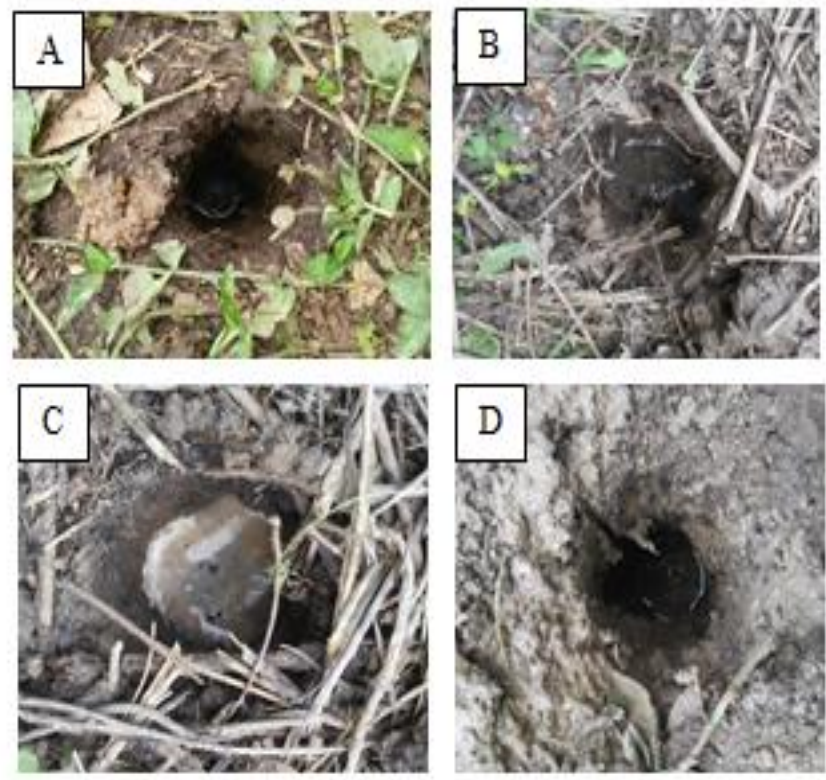

Figure 2. A, B, C, D. Different test conditions for obtaining satisfactory readings.

A graduated ruler was used to perform depth readings along the hole made in the soil. Also, to facilitate the readings a circuit with an LED was installed so that, whenever there was an increase of the height of the sheet, the LED was used as indicator (Figure 4D).

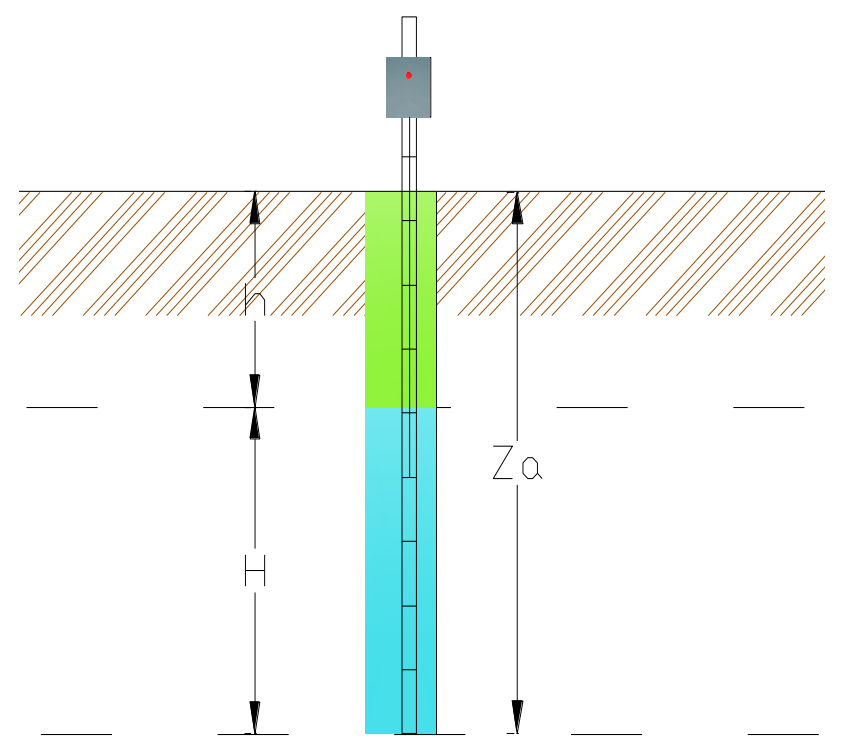

Figure 3. Schematic of the well with the respective parameters to estimate the hydraulic conductivity. Height of readings $(\mathrm{H})$; Height of well (Za); and Height of the surface at the level of the water table $(h)$.
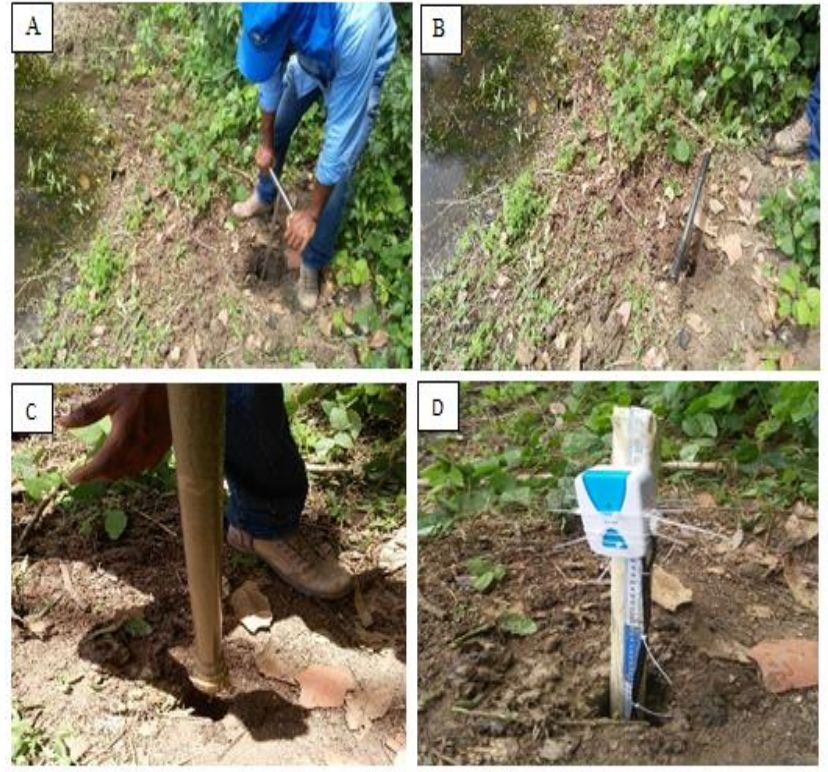

Figure 4. Procedure step by step. A - Well bore; B - Depth check; C - Removal of water to "zero" the current level of the sheet; and D - Equipment indicating the variation of the level of the water table.

In order to determine and obtain the results, a time variation of 10 minutes between each reading was established, that is, at each time variation, a height reading was made at the water level in the well. In order to estimate the hydraulic conductivity, several empirical formulas have been proposed, such as Ernst's, which is the model that most closely approximates the soil situation studied. The proposed model is presented by Equation 1:

$$
k=\frac{400}{\left(\frac{H}{r}+20\right)\left(2-\frac{Y}{H}\right)} \frac{r}{Y} \frac{\Delta Y}{\Delta t}
$$

Where: $\mathrm{K}=$ soil hydraulic conductivity $\left(\mathrm{m} \mathrm{d}^{-1}\right)$; $\mathrm{H}=$ distance between the water table level and the bottom of the well $(\mathrm{cm}) ; r=$ well radius $(\mathrm{cm}) ; Y=$ distance from the water level in the well to the level of the water table, relative to each measurement interval $(\mathrm{cm})$; $\Delta \mathrm{Y}=$ change in water level in the well at time intervals (previous reading minus current reading) (cm); and $\Delta \mathrm{t}=$ time interval relative to each height measurement (s).

\section{RESULTS AND DISCUSSION}

The time intervals for each height measurement $(\Delta t)$, the distance between the water table and the bottom of 
the well $(H)$, the radius of the well $r$, variation of the water level in the well are shown in Table $1(\Delta \mathrm{Y})$, distance from the water level in the well at groundwater level $(Y)$, and hydraulic conductivity for wells 1,2 and 3, respectively.

For the accomplishment of the field work, the reading was of great importance in the calculation of the hydraulic conductivity of the studied soil. This calculation was adapted by the Ernst equation, as demonstrated by Mello and Silva (2007), the values being adjusted.

For all values of $r, 5 \mathrm{~cm}$ were obtained; $\mathrm{H}$ ranged from 40.1 to $50.6 \mathrm{~cm}$; to $Y$ had the same values for both $30 \mathrm{~cm}$ wells, and $\Delta \mathrm{Y}$ between 50 and $55 \mathrm{~cm}$. The hydraulic conductivity values for the studied soil obtained by the Auger-Hole method ranged from 0.24821 to $0.28544 \mathrm{~m}$ day $^{-1}$. With a mean value for hydraulic conductivity of $0.286835 \mathrm{~m} \mathrm{day}^{-1}$ was considered slow. Millar (1988) states that values of hydraulic conductivity between 0.1 to $0.5 \mathrm{~cm} \mathrm{~h}^{-1}$ is considered slow and values between 0.5 $2.0 \mathrm{~cm} \mathrm{~h}^{-1}$, is moderate.

Table 1. Runoff readings of the water level in the well and calculation of the hydraulic conductivity by the Auger-Hole method

\begin{tabular}{ccccccc}
\hline $\begin{array}{c}\text { Observation } \\
\text { well }\end{array}$ & $\begin{array}{c}\boldsymbol{\Delta t} \\
(\mathbf{s})\end{array}$ & $\begin{array}{c}\mathbf{H} \\
(\mathbf{c m})\end{array}$ & $\begin{array}{c}\mathbf{r} \\
(\mathbf{c m})\end{array}$ & $\begin{array}{c}\Delta \mathbf{Y} \\
(\mathbf{c m})\end{array}$ & $\begin{array}{c}\mathbf{Y} \\
(\mathbf{c m})\end{array}$ & $\begin{array}{c}\mathbf{K} \\
\left(\mathbf{m} \text { day }^{-1}\right)\end{array}$ \\
\hline $\mathbf{1}$ & 600 & 40.1 & 5 & 50 & 30 & 0.24821 \\
$\mathbf{2}$ & 600 & 45.6 & 5 & 53 & 30 & 0.27141 \\
$\mathbf{3}$ & 600 & 50,6 & 5 & 55 & 30 & 0.28544 \\
$\begin{array}{c}\text { Average } \\
\text { Standard } \\
\text { deviation }\end{array}$ & & & & & & 0.26835 \\
Variance & & & & & & 0.01342 \\
\hline
\end{tabular}

Oliveira (2005) evaluated the impact of grazing on hydraulic conductivity in pasture and native cerrado using the laboratory method of constant load permeability and the field method using permeameter achieved conductivity variation of the order of 0.66 to $40.64 \mathrm{~cm} \mathrm{~h}^{-1}$ and 1.9 to $23.14 \mathrm{~cm} \mathrm{~h}^{-1}$ respectively. The hydraulic conductivity for well 1 was $0.24821 \mathrm{~m}$ day $^{-1}$.

Corroborating with this research, close values were found by Souza et al. (2014), analyzing soil hydrodynamics in Cariri, State of Paraíba, obtained a hydraulic conductivity value of $0.96 \mathrm{~m} \mathrm{day}^{-1}$ using the Porchet method (Auger-Role Inverse). Table 2 shows the classes of soils with saturated hydraulic conductivity values.

Taking into account Table 2 and the results of hydraulic conductivity obtained in the referred study, hydraulic conductivity with a value of $0.24821 \mathrm{~m} \mathrm{day}^{-1}$ belongs to the class of clayey soils. The wells 2 and 3 being also the same class of soils as the observation well
1. These results are consistent considering that soil of medium sand is characterized by the size of the pores that influences the movement of water in the soil.

Table 2. Class of soils with saturated hydraulic conductivity values $\left(\mathrm{m} \mathrm{day}^{-1}\right)$.

\begin{tabular}{cc}
\hline Common values of $\mathbf{K}$ & $\mathbf{K}(\mathbf{m} /$ day) \\
\hline Soils clay (close to surface) & $0,01-0,2$ \\
Clay soils (compacted layer) & $1 \times 10^{-8}-0,01$ \\
Free ground (silt) & $0,1-1,0$ \\
Thin sand & $1-5$ \\
Average sand & $5-20$ \\
Coarse sand & $20-100$ \\
Clay + sand + gravel & $0,001-0,1$ \\
\hline
\end{tabular}

This factor, according to Klar (1984), is the main agent that allows the sandy soils to present higher values of hydraulic conductivity, in saturation condition than those of finer texture. Table 3 shows the classes of hydraulic conductivity that varies from very slow $\left(0.125 \mathrm{~cm} \mathrm{~h}^{-1}\right)$ to very fast (>25 $\mathrm{cm} \mathrm{h}^{-1}$ ) (FREIRE et al., 2003).

Table 3. Classification of hydraulic conductivity in saturated medium in $\mathrm{cm} \mathrm{h}^{-1}$

\begin{tabular}{cc}
\hline Ranking & Interval \\
\hline Very slow & $<0.125$ \\
Slow & $0.125-0.5$ \\
Moderately Slow & $0.5-2.0$ \\
Moderate & $2.0-6.25$ \\
Moderately Fast & $6.25-12.5$ \\
Fast & $12.5-25$ \\
Very fast & $>25$ \\
\hline
\end{tabular}

Analyzing the hydraulic conductivity data obtained in Table 1, the soil under analysis is classified in slow saturated hydraulic conductivity. According to Morelli and Ferreira (1987), is mainly due to the following reasons: the volume of soil sampled is higher, even for the methods considered as punctual; the soil structure undergoes less change and the value of the hydraulic conductivity is determined according to the predominant direction of water flow to the drains of the future drainage system, the movement is predominantly horizontal.

Results similar to this research were found by Trevissan et al. (2009), who evaluated the hydraulic conductivity in a Red Latosol with clayey texture in the region of Piracicaba-SP, where they classified the conductivity from slow to moderate. 


\section{CONCLUSÕES}

The hydraulic conductivity values using the Auger-Hole method were classified as slow, with values ranging from 0.24821 to $0.28544 \mathrm{~m} \mathrm{day}^{-1}$, and a mean of $0.26835 \mathrm{~m}$ day $^{-1}$. This method proved to be practical, fast, safe and easy to handle.

\section{ACKNOWLEDGMENTS}

To the Research Group registered in the National Council of Research and Technological Development (CNPq) in Food, Chemistry, Agronomy and Water Resources.

\section{REFERÊNCIAS}

D'ANGIOLELLA, G.L.B. et al. Climatic Trends for Coastal Tracks in the Region of Cruz das Almas. Brazilian Congress of Agricultural Engineering, p.43-45, 1998.

FERREIRA, A.P. Drainage of agricultural land. Viçosa: UFV, 2002.

FEITOZA, M.Z.N. Estimation of drainage porosity by different methodologies. Dissertation (Master in Soil Science) Federal Rural University of Pernambuco, Recife, 2006. 48p.

FREIRE, M.B.G.S. et al. Hydraulic conductivity of Pernambuco soils in response to electrical conductivity and RAS of irrigation water. Brazilian Journal of Agricultural and Environmental Engineering, v.7, n.1, p.45-52, 2003.

GASPAR, M.T.G. Urucuia Aquifer System: regional characterization and management proposals. Thesis (Doctorate in Geoscience) - University of Brasília, 2006. 158p.

GOOGLE EARTH. Experimental area of EMBRAPA. 2017. Available in: https://earth.google.com/web/

GONÇALVES, A.D.; LIBARDI, P.L. Analysis of the soil hydraulic conductivity determination by the instantaneous profile method. Brazilian Science Review, v.37, n.5, p.1174-1184, 2013.

GUERRA, H.O.C. Soil Physics. Campina Grande: UFCG, 2000.

KLAR, A.E. Water in the soil - plant - atmosphere system. São Paulo: Nobel, 1984.

MELLO, P.L.Z.; SILVA, B.D.L. Agricultural Drainage. Federal Rural University of Rio de Janeiro, 2007.

MILLAR, A. Drainage of agricultural land: agronomic bases. São Paulo: Editerra Editorial, 1988.

MORELLI, M.; FERREIRA, E.B. Effect of calcium carbonate and diammonium phosphate on electrochemical and physical properties of an Oxisol. Brazilian Journal of Soil Science, v.11, 16, 1987.

OLIVEIRA, F.A. Impact of grazing on the hydraulic conductivity of Latosol under pasture and native cerrado. Monograph
(Graduate monograph) - University of Brasília, 2005, 87p.

SOUZA, F.G. et al. Soil hydrodynamics in an area for family agriculture in the Paraíba region. Green Magazine on Agroecology and Sustainable Development, v.9, n.1, p.13-27, Mossoró, RN, 2014.

SOUZA, L.S.; SOUZA, L.D. Physical-water characterization of soils of the National Center for Research on Cassava and Tropical Fruits, Cruz das Almas, Bahia. Search Bulletin: EMBRAPA /CNPMF, n.20, 2001.

SCHOSSLER, T.R. et al. Salinity: effects on physiology and mineral nutrition of plants. Encyclopedia Biosphere, v.8, n.15; p.15631578, 2012.

TREVISAN, R. et al. Hydraulic conductivity of the saturated soil in the vadose zone in situ and in the laboratory. Irriga, v.14, n.3, p.413-422. 